\title{
1,5-Prodan Emits from a Planar Intramolecular Charge-Transfer Excited State
}

Tao Chen

College of William and Mary

Samuel W. Lee

College of William and Mary

Christopher J. Abelt

College of William and Mary, cjabel@wm.edu

Follow this and additional works at: https://scholarworks.wm.edu/aspubs

\section{Recommended Citation}

Chen, Tao; Lee, Samuel W.; and Abelt, Christopher J., 1,5-Prodan Emits from a Planar Intramolecular Charge-Transfer Excited State (2018). ACS OMEGA, 3(5), 4816-4823.

$10.1021 /$ acsomega. 8 b00423

This Article is brought to you for free and open access by the Arts and Sciences at W\&M ScholarWorks. It has been accepted for inclusion in Arts \& Sciences Articles by an authorized administrator of W\&M ScholarWorks. For more information, please contact scholarworks@wm.edu. 


\title{
1,5-Prodan Emits from a Planar Intramolecular Charge-Transfer Excited State
}

\author{
Tao Chen, Samuel W. Lee, and Christopher J. Abelt*(-) \\ Department of Chemistry, College of William and Mary, Williamsburg, Virginia 23185, United States \\ Supporting Information
}

ABSTRACT: 1-Propionyl-5-dimethylaminonaphthalene (8, 1,5-Prodan) and two derivatives where the amino group is constrained in a seven-membered (9) and fivemembered (10) ring are prepared. All three exhibit strong fluorescence and similar degrees of solvatochromism. Their fluorescence is strongly quenched in alcohol solvents. Because the amino group in $\mathbf{9}$ and especially $\mathbf{1 0}$ is forced to be coplanar with the naphthalene ring, the similar photophysical behavior of all three suggests that emission arises from a planar excited state (planar intramolecular charge transfer).

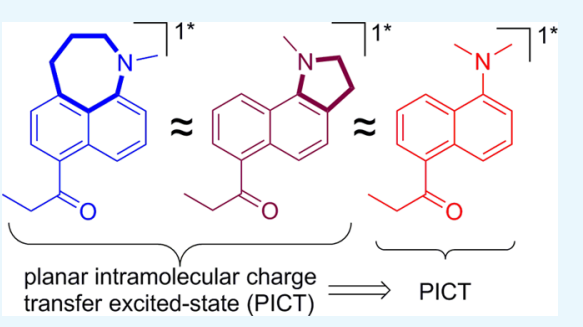

\section{INTRODUCTION}

Prodan (6-propionyl-2-dimethyaminonaphthalene), 1, is a highly fluorescent molecule whose Stokes shift varies strongly with solvent polarity. ${ }^{1}$ Its excited state has a dipole moment that is nearly double that of the ground state because of intramolecular charge transfer (ICT) from the amino group. ${ }^{2-5}$ The nature of the emissive excited state has been the subject of many studies. In nonpolar environments, fluorescence is thought to occur from a locally excited (LE) state whose structure is similar to that of the ground state. In fact, the LE state may be the second excited state $\left(S_{2}\right){ }^{6}$ In polar solvents, the excited state relaxes through ICT. Studies in micelles ${ }^{7}$ and reverse micelles ${ }^{8-11}$ are particularly insightful because both states are present as a result of partitioning between the heterogeneous environments. Whether the ICT state is accompanied by twisting about the dimethyl amino group (N-TICT) or possibly the propionyl group (O-TICT) is still debated. $^{12-14}$ Calculations tend to support a planar ICT (PICT) excited state where neither group twists. ${ }^{15,16}$ The related compound, dimethylaminobenzonitrile (Dmabn, 2, Figure 1), is known to emit from a twisted ICT (TICT) excited-state. The strongest evidence for this conclusion comes from the behavior of constrained Dmabn derivatives. Compound 3 locks the amino group in a small ring, and it shows only LE emission. ${ }^{17,18}$ Compound 4 locks the amino group in an orthogonal orientation, and it shows ICT emission. $^{18,19}$<smiles>CCC(=O)c1ccc2cc(N(C)C)ccc2c1</smiles>

2,6-Prodan (1)

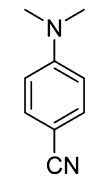

Dmabn (2)

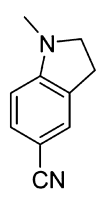

3

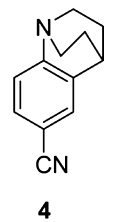

4
Figure 1. Structures of Prodan (1), Dmabn (2), and two constrained derivatives 3 and 4 .
We have taken a similar approach to elucidating the structure of the emissive ICT state in Prodan. Derivatives (Figure 2) with
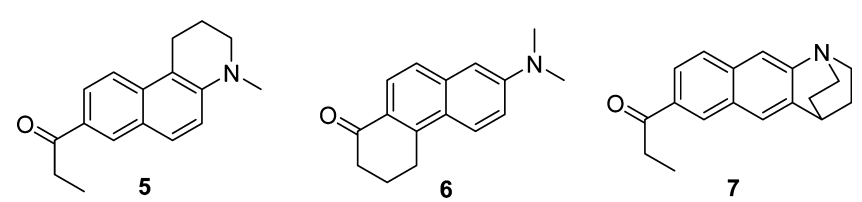

Figure 2. Structures of constrained Prodan derivatives 5-7.

a forced planar amino group $(5)^{20}$ or propionyl group $(6)^{21}$ show a fluorescence behavior that is similar to Prodan, while the twisted derivative 7 does not fluoresce. ${ }^{22}$ Thus, the behavior of the three model compounds suggests that Prodan emits from a PICT state and not from a TICT state.

Of the several regioisomers of Prodan, the 1,5-derivative (Figure 3) should be a strong fluorophore. While a derivative with an ethanoyl group was reported by Turro and Sames et $a^{2} .{ }^{23}$ others bearing a cyclopenta $[b]$-ring fusion have been studied extensively by Brummond et al. ${ }^{24,25}$ The fused ring was not expected to significantly perturb the inherent photophysical behavior. The latter derivatives fluoresce nearly as strongly as 2,6-Prodan. Moreover, they absorb at shorter wavelengths, and they show large Stokes shifts. Unlike 2,6-Prodan, they are quenched in protic solvents. This research group has made a number of derivatives for bioconjugation studies. ${ }^{26}$

1,5-Prodan bears a striking similarity to the dansyl chromophore (Figure 3). Both have a dimethylamino electron-donating group in the 1-position and an electronwithdrawing group in the 5-position. The dansyl group is often used in the fluorescence tagging of proteins. ${ }^{27,28}$ The solvatochromism seen in these dansyl-tagged biomolecules has been interpreted assuming that the dansyl group emits from

Received: March 6, 2018

Accepted: April 20, 2018

Published: May 2, 2018 

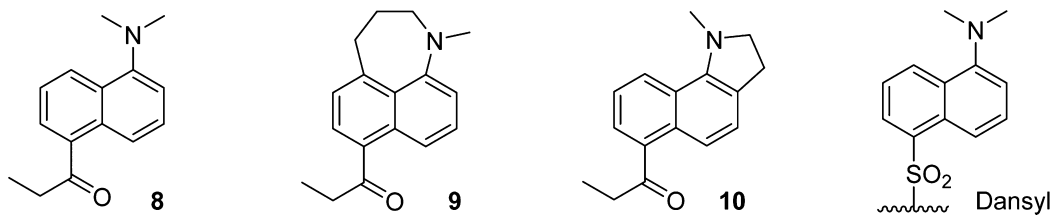

Figure 3. Structures of 1,5-Prodan (8), constrained derivatives 9 and 10, and the dansyl group.

Scheme 1. Preparation of 8-10
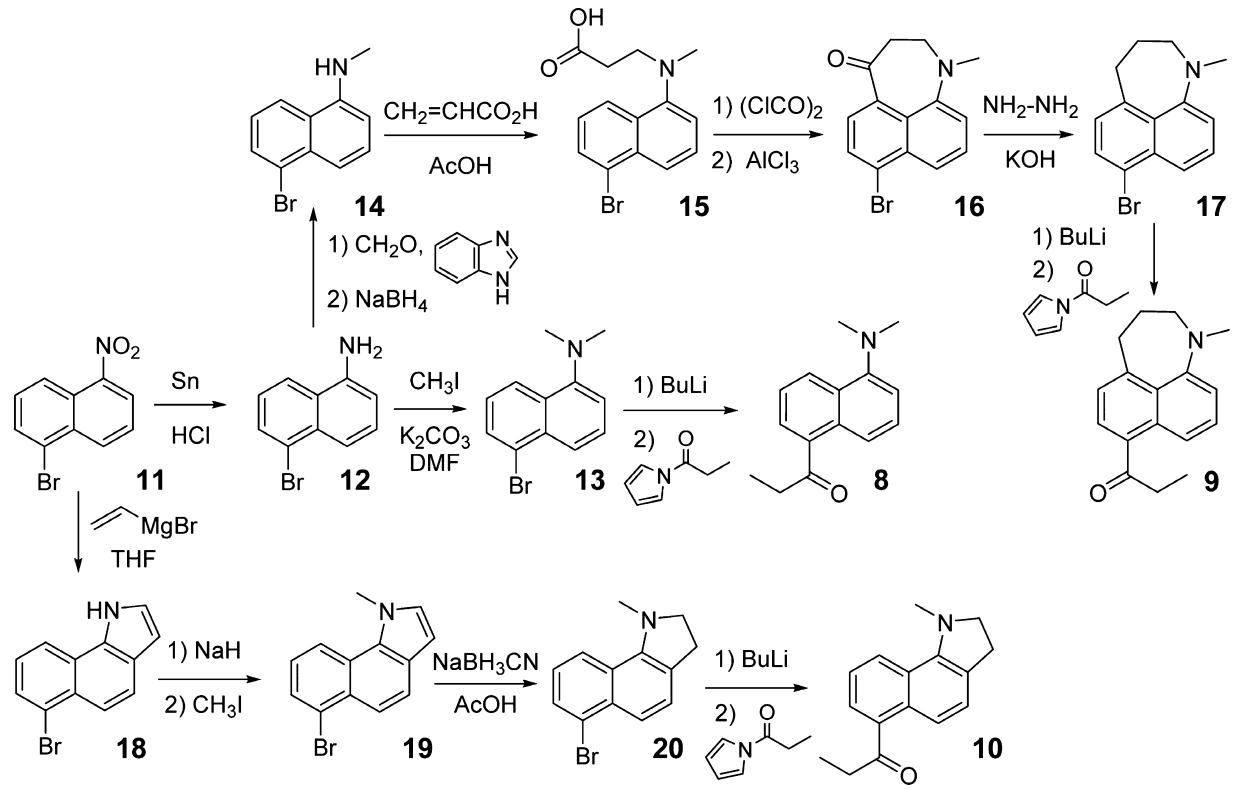

a TICT excited state. ${ }^{29,30}$ We wondered if 1,5-Prodan might also emit from a TICT state. This paper reports the preparation of 1,5 -Prodan $(8)$ and two derivatives $(9,10)$ where the amino group is locked in a ring structure and compares their photophysical behavior.

\section{RESULTS AND DISCUSSION}

Compounds 8-10 were prepared using the routes in Scheme 1. The synthesis of the parent compound 8 follows the same route as our synthesis of Prodan. ${ }^{31}$ In the synthesis of $\mathbf{9}$, we were hoping that the carboxylic acid produced from the Michael addition of acrylic acid would cyclize adjacent to the amino group. Heating this acid in polyphosphoric acid at $120{ }^{\circ} \mathrm{C}$ did generate some of this isomer, but it mostly gave the methylamino precursor via a retro-Michael addition. The intramolecular Friedel-Crafts reaction of the carboxylic acid chloride is conducted at $40{ }^{\circ} \mathrm{C}$, and cyclization occurs at the $\alpha$ naphthalene position of the adjoining ring. The preparation of 10 makes use of an initial Bartoli indole synthesis. ${ }^{32,33}$

The absorption and emission behavior of $\mathbf{8 - 1 0}$ are consistent with that of the reported cyclopentane-fused 1,5Prodan derivative. Brummond et al. found that the latter has fluorescence quantum yields that are about $60 \%$ of those for 2,6-Prodan (1) across a range of aprotic solvents. ${ }^{24}$ The relative quantum yields for 8-10 were determined in toluene using anthracene $(\Phi=0.30)$ as a reference. They are $0.42 \pm 0.03$, $0.40 \pm 0.07$, and $0.12 \pm 0.01$, respectively. The remaining reported yields in Table 1 are relative to these assignments. The absorption maxima of these compounds varies little with solvent: $332 \pm 3 \mathrm{~nm}, 339 \pm 3 \mathrm{~nm}$, and $351 \pm 3 \mathrm{~nm}$ for $\mathbf{8 - 1 0}$,
Table 1. Fluorescence Quantum Yields $\left(\Phi_{\mathrm{f}}\right)$ and Emission Maxima $\left(\lambda_{\mathrm{em}}\right)$ for 8-10 in Various Solvents ${ }^{a}$

\begin{tabular}{|c|c|c|c|c|c|c|}
\hline \multirow[b]{2}{*}{ solvent } & \multicolumn{2}{|c|}{8} & \multicolumn{2}{|c|}{9} & \multicolumn{2}{|c|}{10} \\
\hline & $\Phi_{\mathrm{f}}$ & $\lambda_{\mathrm{em}}(\mathrm{nm})$ & $\Phi_{\mathrm{f}}$ & $\lambda_{\mathrm{em}}(\mathrm{nm})$ & $\Phi_{\mathrm{f}}$ & $\lambda_{\mathrm{em}}(\mathrm{nm})$ \\
\hline Tol & 0.42 & 544 & 0.40 & 549 & 0.12 & 611 \\
\hline $\mathrm{PhCl}$ & 0.44 & 557 & 0.43 & 556 & 0.086 & 627 \\
\hline $\mathrm{CH}_{2} \mathrm{Cl}_{2}$ & 0.33 & 579 & 0.59 & 576 & 0.044 & 653 \\
\hline EtOAc & 0.24 & 569 & 0.30 & 563 & 0.035 & 639 \\
\hline $\mathrm{Et}_{2} \mathrm{O}$ & 0.35 & 544 & 0.37 & 548 & 0.086 & 606 \\
\hline $\mathrm{Me}_{2} \mathrm{CO}$ & 0.18 & 591 & 0.27 & 580 & 0.041 & 666 \\
\hline $\mathrm{MeCN}$ & 0.13 & 609 & 0.20 & 595 & 0.015 & 689 \\
\hline DMSO & 0.12 & 617 & 0.26 & 600 & 0.016 & 698 \\
\hline iPrOH & 0.021 & 636 & 0.045 & 633 & 0.004 & 690 \\
\hline $\mathrm{BuOH}$ & 0.018 & 632 & 0.020 & 635 & 0.005 & 692 \\
\hline $\mathrm{PrOH}$ & 0.014 & 642 & 0.026 & 640 & 0.002 & 699 \\
\hline EtOH & 0.010 & 651 & 0.020 & 645 & 0.004 & 699 \\
\hline $\mathrm{MeOH}$ & 0.003 & 676 & 0.009 & 661 & $<0.001$ & \\
\hline
\end{tabular}

${ }^{a}$ Solvents are listed in Figures S1-S3.

respectively. Fluorescence spectra of $\mathbf{8 - 1 0}$ are shown in Figures S1-S3.

Relative to 8, constraining the amino group in a 7-membered ring (9) has little impact on the quantum yields and the absorption and emission positions. For the five-membered ring (10), however, both the absorption and emission maxima are significantly shifted to the red. One consequence of the emission red shift is that the fluorescence quantum yield is reduced because of the smaller energy gap between the excited state and the ground state. The origins of the red shifts in $\mathbf{1 0}$ are addressed in the computational modeling section (vide 
infra). All three compounds show strong fluorescence quenching in alcohols.

Despite the red-shifting in $\mathbf{1 0}$ relative to $\mathbf{8}$ and $\mathbf{9}$, all three show a similar ICT in the excited state. The displacement of electron density from the amino group to the carbonyl group gives rise to an increase in the molecular dipole moment. Higher polarity solvents are better able to stabilize the excited state, and, as a result, emission occurs at longer wavelengths. The degree of charge transfer is reflected in the magnitude of the solvatochromism. Figure 4 shows the solvatochromic

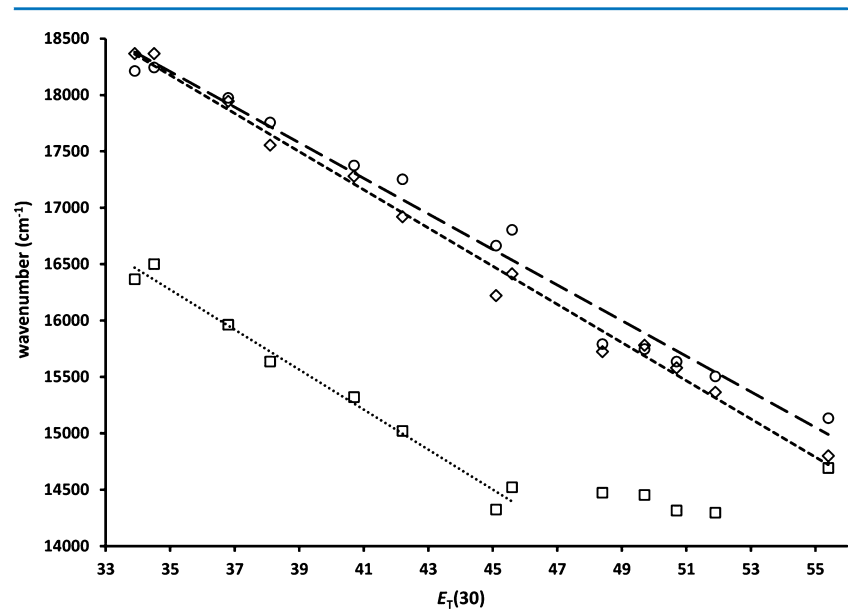

Figure 4. Plot of emission maximum $\left(\tilde{\nu}, \mathrm{cm}^{-1}\right)$ vs $E_{\mathrm{T}}(30)$ for $\mathbf{8}(\diamond,---)$, $9(\bigcirc,---)$ and $10(\square, \cdots)$. Solvents are toluene, chlorobenzene, ethyl ether, methylene chloride, ethyl acetate, acetone, dimethyl sulfoxide, acetonitrile, isopropanol, butanol, propanol, ethanol, and methanol.

behavior for 8-10. In these graphs, the emission maximum (wavenumbers) is plotted versus Reichardt's $E_{\mathrm{T}}(30)$ parameter. ${ }^{34}$ The latter is a composite scale used to characterize both the solvent polarity and the effect of solvent H-bonding. For Prodan and derivatives, multilinear regression analysis shows that their solvatochromism depends primarily on the polarity of the solvent but also slightly on the solvent acidity ( $\mathrm{H}$-bond donating ability). ${ }^{35-37}$ The three plots in Figure 4 are roughly linear for the aprotic solvents. The slopes of the best-fit lines are shown in Table 2. While the plots for 8 and $\mathbf{9}$ are linear

Table 2. Slopes of the Solvatochromism Plots of $\tilde{\nu}$ vs $E_{\mathrm{T}}(30)$ for $8-10^{a}$

\begin{tabular}{llll|} 
& \multicolumn{1}{c}{$\mathbf{8}$} & \multicolumn{1}{c}{$\mathbf{9}$} & $\mathbf{1 0}^{b}$ \\
slope & -169 & -158 & -156 \\
std error & $(5)$ & $(7)$ & $(14)$ \\
$R^{2}$ & 0.99 & 0.98 & 0.95
\end{tabular}

${ }^{a}$ Values in parentheses are from the regression analysis of the linear correlation. ${ }^{b}$ Slope calculation excluding protic solvents.

with the protic solvents included, the plot for $\mathbf{1 0}$ is not. The deviations with the protic solvents are probably related to the extreme quenching in 10. One explanation for the deviation in the plot is that the H-bonding deactivation distorts the population of excited species, leaving only those of higher energy (more poorly H-bonded) to fluoresce. Alternatively, finding an emission maximum for a nearly completely quenched chromophore is problematic. While comparisons of 10 with 8 and 9 require some caution, there is no significant difference between the slopes for these compounds in aprotic solvents. Because the magnitude of the slopes is a reflection of the increase in the dipole moment of the excited state, all three must experience a similar degree of charge transfer in their excited states. Fluorophores $\mathbf{9}$ and $\mathbf{1 0}$ can only form a PICT excited state because the ring systems do not allow orthogonal twisting.

We have found that certain 2,6-Prodan derivatives are strongly quenched in alcohol solvents. In the excited state, the $\mathrm{H}$-bonding interaction with the carbonyl becomes stronger as a result of the ICT. H-Bonding interactions with two solvent molecules have been implicated in the quenching mechanism, ${ }^{38}$ and the magnitude of quenching can be used as a sensor of solvent acidity. ${ }^{38,39}$ In Figure 5, the order of magnitude

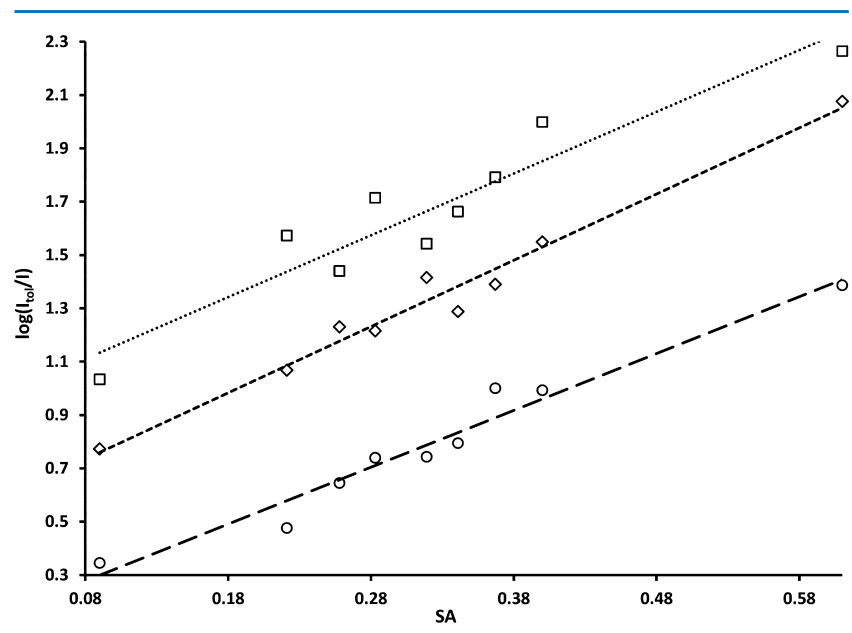

Figure 5. Plots of $\log \left(I_{\text {tol }} / I_{\text {solvent }}\right)$ vs SA for $8(\diamond,---), 9(\bigcirc,---)$ and $10(\square, \cdots)$. Solvents (SA values) are 2-octanol (0.09), 2-butanol (0.22), cyclopentanol (0.26), 2-propanol (0.28), 1-pentanol (0.32), 1butanol (0.34), 1-propanol (0.37), ethanol (0.40), and methanol $(0.61)$.

quenching is captured by taking the $\log _{10}$ of the ratio of $I_{\text {tol }} / I$ where $I$ refers to the fluorescence intensity maximum for a given solvent and $I_{\text {tol }}$ is the intensity in toluene. These values are plotted versus Catalán's solvent acidity parameter, SA, a measure of the H-bond donating ability of the solvent. The intensity in toluene, where there is no H-bond induced quenching, is used as a reference. The plots are approximately linear over the range of alcohol solvents. The slopes are shown in Table 3 together with previous results with several 2,6Prodan derivatives (Figures 2 and 6). The slopes for 8-10 are within the standard error of each other with an average of 2.3. The slopes for 1, 5-6 are also tightly clustered, but their average is much smaller (0.70). The slopes for 22-24 also fall close together, but their average (2.1) is much closer to that for 8-10. The clustering behavior for these three sets of compounds suggests that the $\mathrm{H}$-bonding interactions are similar within each set and by extension that the charge densities of the carbonyl groups in the excited states are also similar. The stronger quenching for 22-24 relative to $\mathbf{1 , 5 - 6}$ was ascribed to the carbonyl group being slightly twisted out of the plane of the naphthalene ring. ${ }^{37}$ In compounds 23-24, the tert-butyl group forces the nonplanarity, while in $\mathbf{2 2}$, it is the seven-membered ring. Evidently, these slight structural deviations turn on an efficient deactivation channel to the ground state with H-bonded complexes. With compounds 810, a similar deviation arises from the steric interaction with the 
Table 3. Slopes of the Quenching Plots in Figure 5 for 8-10 Compared with 2,6-Prodan (1) and Derivatives 5-6 (Figure 2) and 21-23 (Figure 6)

\begin{tabular}{|c|c|c|c|c|c|c|c|c|c|}
\hline & 8 & 9 & 10 & 1 & 5 & 6 & 21 & 22 & 23 \\
\hline Slope & 2.48 & 2.13 & 2.32 & 0.74 & 0.74 & 0.60 & 1.96 & 2.20 & 2.02 \\
\hline std error & $(0.15)$ & $(0.17)$ & $(0.29)$ & $(0.08)$ & $(0.05)$ & $(0.08)$ & $(0.07)$ & $(0.13)$ & $(0.19)$ \\
\hline$R^{2}$ & 0.98 & 0.96 & 0.90 & 0.93 & 0.97 & 0.88 & 0.99 & 0.97 & 0.94 \\
\hline
\end{tabular}

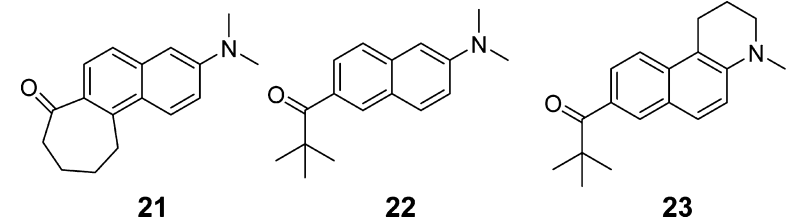

Figure 6. Structures of 2,6-Prodan derivatives 21-23.

peri-H (vide infra). The similarity in the H-bond quenching behavior of 8-10 corroborates their comparable levels of charge transfer in the excited states.

Structures for the ground and excited states were determined using computational modeling. As with our previous work with 2,6-Prodan derivatives, we used the semiempirical AM1 method employing a high level of configurational interactions and a solvation method. ${ }^{20-22}$ More recent TDDFT calculations are in agreement with the AM1 results. ${ }^{16}$ Figure S4 shows that the calculated solvatochromism tracks the experimentally observed values in a linear fashion. The SM5C solvent model captures two-thirds to three-fourths of the experimental solvatochromism. A recent study showed similar but better results with a COSMO model $(\sim 85 \%) .{ }^{40}$ This model was less effective here.

The values from several specific structural features are collected in Table 4. The behavior of the carbonyl and amino

Table 4. Comparison of Calculated Values for 8-10

\begin{tabular}{|c|c|c|c|c|c|c|}
\hline & \multicolumn{2}{|c|}{8} & \multicolumn{2}{|c|}{9} & \multicolumn{2}{|c|}{10} \\
\hline & $\mathrm{S}_{0}$ & $S_{1}$ & $\mathrm{~S}_{0}$ & $\mathrm{~S}_{1}$ & $S_{0}$ & $S_{1}$ \\
\hline abs/em $\left(\mathrm{cm}^{-1}\right)$ & 28600 & 21200 & 28100 & 21400 & 27500 & 20400 \\
\hline abs/em (nm) & 350 & 472 & 356 & 467 & 363 & 490 \\
\hline $\mathrm{C}_{10}-\mathrm{C}_{5}-\mathrm{CO}(\mathrm{deg})$ & 55 & 6 & 40 & 13 & 59 & 16 \\
\hline $\mathrm{C}=\underset{(\AA)}{=} \mathrm{O}$ bond length & 1.24 & 1.26 & 1.24 & 1.26 & 1.24 & 1.25 \\
\hline $\begin{array}{l}\mathrm{C}_{5}-\mathrm{CO} \text { bond length } \\
(\AA)\end{array}$ & 1.49 & 1.44 & 1.49 & 1.44 & 1.49 & 1.44 \\
\hline charge on $\mathrm{O}$ (a.u.) & -0.34 & -0.43 & -0.34 & -0.42 & -0.34 & -0.42 \\
\hline $\mathrm{C}-\mathrm{C}_{1}-\mathrm{N}-\mathrm{C}(\mathrm{deg})^{a}$ & 53 & 17 & 40 & 33 & 22 & 3 \\
\hline $\mathrm{N}$ hybridization $\left(\mathrm{sp}^{x}\right)$ & 2.24 & 1.95 & 2.12 & 1.97 & 2.22 & 1.94 \\
\hline $\begin{array}{l}\mathrm{C}_{1}-\mathrm{N} \text { bond length } \\
(\AA)\end{array}$ & 1.43 & 1.36 & 1.41 & 1.36 & 1.42 & 1.36 \\
\hline charge on $\mathrm{N}$ (a.u.) & -0.25 & -0.11 & -0.27 & -0.12 & -0.23 & -0.12 \\
\hline dipole moment (D) & 3.1 & 10.3 & 4.7 & 10.1 & 3.1 & 10.9 \\
\hline
\end{tabular}

portions are most revealing. In the ground state, both the carbonyl group and the amino group are twisted out of plane by $\sim 50^{\circ}$ and $\sim 40^{\circ}$, respectively. In the excited state, the carbonyl becomes nearly planar $\left(\sim 10^{\circ}\right)$, while the amino group is less twisted $\left(\sim 20^{\circ}\right)$. These changes in dihedral angles are also accompanied by changes in bond lengths. Partial $\pi$-bonding occurs between the naphthalene ring and the amino $\mathrm{N}$ and carbonyl $\mathrm{C}$ with a decrease in the carbonyl bond order. The $\mathrm{N}$ atom also becomes less pyramidal. The charge-transfer characteristic of the excited state is shown by the $\mathrm{N}$ atom decrease and the carbonyl oxygen increase in the negative charge. The similarity in these behaviors for all three compounds further supports the postulate of a PICT excited state.

The unusual behavior of $\mathbf{1 0}$ with respect to its absorption and emission positions is also captured by the computational results. The emission maximum for $\mathbf{1 0}$ is predicted to be shifted to the red by $900 \mathrm{~cm}^{-1}$ and its absorption by $850 \mathrm{~cm}^{-1}$. The other noticeable feature in the table is that the amino group in 10 is barely twisted in the ground state (about half as much) and essentially planar in the excited state (vs $20^{\circ}$ ). The excited state dipole moment is slightly greater for $\mathbf{1 0}$. The enforced planarity of the amino group in $\mathbf{1 0}$ is likely responsible for its differing behavior relative to 8 and $\mathbf{9}$. The greater conjugation of the amino group leads to a slightly higher energy highest occupied molecular orbital and a lower energy lowest unoccupied molecular orbital (Figure S8).

\section{CONCLUSIONS}

The photophysical behavior of two constrained derivatives (9 and 10) was compared with that of 1,5-Prodan (8). The former fluorophores can only emit from a PICT excited state because the amino group is locked in a seven- and five-membered ring, respectively. The change in the emission maxima in response to solvent polarity (solvatochromism) is a reflection of the excited-state dipole moment and hence the degree of ICT. Amino group twisting should result in a large ICT because of the resulting electronic decoupling with the aromatic system. However, all three show a similar level of solvatochromism in aprotic solvents. Further, ICT also results in increased $\mathrm{H}$ bonding with the carbonyl oxygen in the excited state. With these three chromophores, H-bonding gives rise to efficient quenching. As also seen with $7,{ }^{22}$ orthogonal twisting should give rise to very strong quenching. However, all three show similar sensitivity to $\mathrm{H}$-bond-induced quenching. The planarity enforced by the five-membered ring in $\mathbf{1 0}$ gives rise to redshifting of the absorption and emission maxima, resulting in a smaller quantum yield. Despite this difference in the behavior of 10, the solvatochromism and $\mathrm{H}$-bond quenching results suggest a PICT excited-state structure for all three. By extension, these results cast suspicion on dansyl being a member of the class of TICT chromophores.

\section{EXPERIMENTAL SECTION}

General Information. NMR spectra were obtained with an Agilent DD2-400 or Varian Mercury VX-400 spectrometer. High-resolution ESI-MS were acquired with a Bruker Apex-Qe instrument. All solvents were of spectrophotometric grade. Reagents were obtained from Acros Organics or Sigma-Aldrich. Absorption and fluorescence data were collected using a fiber optic system with an Ocean Optics Maya CCD detector using a miniature deuterium/tungsten lamp and a 366 or $405 \mathrm{~nm}$ LED light source, respectively. Solution cells were thermostated at 23 ${ }^{\circ} \mathrm{C}$. Fluorescence spectra were reported after the following manipulations: (1) the electronic noise was subtracted from the 
raw emission intensity and (2) the wavelength scale was converted to wavenumbers, and the net intensity was multiplied by $\lambda^{2} / \lambda_{\max }^{2}$ to account for the effect of the abscissa-scale conversion. The resulting intensity was divided by the spectral response of the Hamamatsu S10420 CCD. AM1/SM5C semiempirical calculations were conducted using AMPAC 9.1 from Semichem, Inc. Keywords employed were AM1, SDC.I. = $13($ root $=0)$ or $15($ root $=1)$, tight, truste, micros $=0$, scfcrt $=$ 0.

Syntheses (Scheme 1). Compounds 11-13 were prepared as described by Wang et al. ${ }^{41}$ Compound $\mathbf{1 4}$ was prepared following the method of Katritzky et al. for 1-aminonaphthalene. ${ }^{42}$ Propionyl pyrrole was prepared previously. ${ }^{31}$

1-(5-(Dimethylamino)naphthalen-1-yl)propan-1-one (8). A mixture of 5-bromo-1-dimethylaminonaphthalene, 13, (1.57 g, $6.28 \mathrm{mmol}$ ) in tetrahydrofuran (THF; $40 \mathrm{~mL}$ ) was cooled to $-78{ }^{\circ} \mathrm{C}$ under $\mathrm{N}_{2}$. A solution of $n$-BuLi $(4.5 \mathrm{~mL}, 1.6 \mathrm{M})$ in hexanes was added dropwise. The reaction was stirred for 15 min after the addition was complete. Propionyl pyrrole (920 $\mathrm{mg}, 7.48 \mathrm{mmol}$ ) was added slowly keeping the temperature below $-60{ }^{\circ} \mathrm{C}$. The cooling bath was removed, and the mixture was allowed to warm to $-45{ }^{\circ} \mathrm{C}$. Water $(200 \mathrm{~mL})$ was added, and the aqueous layer was extracted twice with $\mathrm{CH}_{2} \mathrm{Cl}_{2}$ (100 $\mathrm{mL}$ ea). The combined organic layers were dried over $\mathrm{CaCl}_{2}$, and the solvent was evaporated in vacuo. The residue was purified by silica gel chromatography using a gradient elution with ethyl acetate in hexanes $(0 \rightarrow 10 \%)$. Fractions containing the compound were combined, concentrated, and distilled under high vacuum (0.2 Torr), giving compound $8(860 \mathrm{mg}$, $60 \%)$ as a light brown oil. ${ }^{1} \mathrm{H}$ NMR $\left(400 \mathrm{MHz}, \mathrm{CDCl}_{3}\right): \delta 7.91$ $(\mathrm{d}, J=8.3 \mathrm{~Hz}, 1 \mathrm{H}), 7.81(\mathrm{~d}, J=7.7 \mathrm{~Hz}, 1 \mathrm{H}), 7.50(\mathrm{dd}, J=8.3$, $7.8 \mathrm{~Hz}, 1 \mathrm{H}), 7.43(\mathrm{~d}, J=7.7 \mathrm{~Hz}, 1 \mathrm{H}), 7.06(\mathrm{~d}, J=7.8 \mathrm{~Hz}, 1 \mathrm{H})$, $3.46(\mathrm{t}, J=6.5 \mathrm{~Hz}, 2 \mathrm{H}), 3.10(\mathrm{t}, J=6.6 \mathrm{~Hz}, 2 \mathrm{H}), 3.02(\mathrm{~s}, 3 \mathrm{H})$; ${ }^{13} \mathrm{C}$ NMR $\left(100 \mathrm{MHz}, \mathrm{CDCl}_{3}\right): \delta 205.40,150.27,138.22$, $133.10,129.96,127.95,127.75,127.20,127.04,120.74,113.33$, 53.64, 44.96, 41.66 .

HRMS (ESI): $[\mathrm{M}+\mathrm{Na}]^{+}$calcd for $\mathrm{C}_{15} \mathrm{H}_{15} \mathrm{NONa}^{+}$, 250.12024; found, 250.12012.

3-((5-Bromonaphthalen-1-yl)(methyl)amino)propanoic Acid (15). 5-Bromo-1-methyl-aminonaphthalene, 14, $(630 \mathrm{mg}$, $2.7 \mathrm{mmol})$, acetic acid $(2 \mathrm{~mL})$ and acrylic acid $(1 \mathrm{~mL})$ were combined and heated to $110{ }^{\circ} \mathrm{C}$ for $1 \mathrm{~h}$. The cooled reaction mixture was poured into ice-cold water $(150 \mathrm{~mL})$. The aq mixture was salted with $\mathrm{NaCl}(35 \mathrm{~g})$ and extracted with EtOAc $(3 \times 100 \mathrm{~mL})$. The combined organic layers were dried with $\mathrm{MgSO}_{4}$ and concentrated in vacuo. The residue was taken up in $\mathrm{CH}_{2} \mathrm{Cl}_{2} /$ hexanes $(50 / 100 \mathrm{~mL})$ and extracted with $1 \mathrm{M} \mathrm{NaOH}$ $(3 \times 150 \mathrm{~mL})$. The combined base layers were acidified to $\mathrm{pH}$ 7 with conc. aq $\mathrm{HCl}$. The aq layer was extracted with $\mathrm{CH}_{2} \mathrm{Cl}_{2}$ $(3 \times 100 \mathrm{~mL})$. The combined organic layers were dried with $\mathrm{MgSO}_{4}$ and concentrated in vacuo, giving the crude Michael adduct, 15, (540 mg, 66\%), which was used without further purification. Note that extended heating of the acetic/acrylic acid solution gives the acetamide derivative of the starting material as a side product. ${ }^{1} \mathrm{H} \mathrm{NMR}\left(400 \mathrm{MHz}, \mathrm{CDCl}_{3}\right): \delta 8.17$ $(\mathrm{d}, J=8.6 \mathrm{~Hz}, 1 \mathrm{H}), 8.06(\mathrm{~d}, J=8.6 \mathrm{~Hz}, 1 \mathrm{H}), 7.79(\mathrm{~d}, J=7.6$ $\mathrm{Hz}, 1 \mathrm{H}), 7.54(\mathrm{t}, J=8.2 \mathrm{~Hz}, 1 \mathrm{H}), 7.34(\mathrm{t}, J=7.6 \mathrm{~Hz}, 1 \mathrm{H}), 7.26$ $(\mathrm{t}, J=8.2 \mathrm{~Hz}, 1 \mathrm{H}), 3.49(\mathrm{t}, J=6.9 \mathrm{~Hz}, 2 \mathrm{H}), 2.89(\mathrm{~s}, 3 \mathrm{H}), 2.63$ (t, $J=6.9 \mathrm{~Hz}, 2 \mathrm{H})$.

7-Bromo-1-methyl-2,3-dihydronaphtho[1,8-bc]azepin4(1H)-one (16). 3-((5-Bromonaphthalen-1-yl)(methyl)amino)propanoic acid, 15, (5.14 g, $16.7 \mathrm{mmol})$ was dissolved in $\mathrm{CH}_{2} \mathrm{Cl}_{2}$ (45 mL). Dimethylformamide (DMF; 20 drops) was added followed by the dropwise addition of oxalyl chloride $(6.64 \mathrm{~g}, 52.7 \mathrm{mmol})$. The reaction was stirred at $0{ }^{\circ} \mathrm{C}$ under $\mathrm{CaCl}_{2}$ drying for $1.5 \mathrm{~h}$. The solvent was removed in vacuo, and the remaining oxalyl chloride was removed under high vacuum. The residue was dissolved in $\mathrm{CH}_{2} \mathrm{Cl}_{2}(75 \mathrm{~mL})$, and aluminum chloride $(6.7 \mathrm{~g}, 19.9 \mathrm{mmol})$ was added. The mixture was heated to reflux for $3 \mathrm{~h}$. The reaction was allowed to cool and then it was quenched with aq $\mathrm{NaHCO}_{3}(12.5 \mathrm{~g} / 300 \mathrm{~mL})$ with stirring. The aq phase was extracted with $10 \% \mathrm{CH}_{2} \mathrm{Cl}_{2} /$ hexanes $(2 \times 75$ $\mathrm{mL}$ ea) and once with $20 \% \mathrm{CH}_{2} \mathrm{Cl}_{2} /$ hexanes $(75 \mathrm{~mL})$. The combined organic layers were washed with ice-cold water (100 $\mathrm{mL}$ ), dried over $\mathrm{Na}_{2} \mathrm{SO}_{4}$, and concentrated in vacuo. The fraction boiling between 160 and $210^{\circ} \mathrm{C}$ at 0.2 Torr gave crude 7-bromo-1-methyl-2,3-dihydronaphtho[1,8-bc]azepin-4(1H)one, 16, (1.3 g, 25\%) which was used without further purification. ${ }^{1} \mathrm{H}$ NMR $\left(400 \mathrm{MHz}, \mathrm{CDCl}_{3}\right): \delta 7.91$ (d, $J=8.6$ $\mathrm{Hz}, 1 \mathrm{H}), 7.81(\mathrm{~d}, J=7.8 \mathrm{~Hz}, 1 \mathrm{H}), 7.50(\mathrm{t}, J=8.0 \mathrm{~Hz}, 1 \mathrm{H}), 7.44$ $(\mathrm{d}, J=7.5 \mathrm{~Hz} 1 \mathrm{H}), 7.06(\mathrm{~d}, J=7.8 \mathrm{~Hz}, 1 \mathrm{H}), 3.46(\mathrm{t}, J=6.7 \mathrm{~Hz}$, $2 \mathrm{H}), 3.10(\mathrm{t}, J=6.5 \mathrm{~Hz}, 2 \mathrm{H}), 2.17(\mathrm{~s}, 3 \mathrm{H})$.

7-Bromo-1-methyl-1,2,3,4-tetrahydronaphtho[1,8-bc]azepine (17). 7-Bromo-1-methyl-2,3-dihydronaphtho[1,8-bc]azepin-4(1H)-one, 16, (3.89 g, $13.4 \mathrm{mmol})$ was dissolved in diethylene glycol $(64 \mathrm{~mL})$. To this solution was added powdered $\mathrm{KOH}(3.0 \mathrm{~g}, 53.5 \mathrm{mmol})$, hydrazine hydrate (5.3 $\mathrm{mL}, 109 \mathrm{mmol})$, and water $(1.3 \mathrm{~mL})$. The mixture was heated to $145{ }^{\circ} \mathrm{C}$ for $30 \mathrm{~min}$ under $\mathrm{N}_{2}$. A Dean-Stark trap was inserted, the mixture was heated to $180{ }^{\circ} \mathrm{C}$ for $4 \mathrm{~h}$, and $1.5 \mathrm{~mL}$ of fluid was collected. The reaction was allowed to cool and then poured into water $(250 \mathrm{~mL})$. The aqueous layer was extracted five times with $\mathrm{CH}_{2} \mathrm{Cl}_{2}$ (50 mL ea). The combined organic layers were diluted with hexanes $(300 \mathrm{~mL})$ and then washed four times with ice-cold water $(125 \mathrm{~mL}$ ea). The organic phase was dried over $\mathrm{MgSO}_{4}$, filtered, and concentrated in vacuo. The first aqueous layer was neutralized with $\mathrm{NH}_{4} \mathrm{Cl}$ and salted out with $\mathrm{NaCl}$. The organic phase that separated was allowed to evaporate, and the residue was combined with the residue from the first organic extractions. The combined residues were distilled under vacuum ( 0.5 Torr). The fractions boiling between 140 and $160{ }^{\circ} \mathrm{C}$ were collected, giving mostly 7-bromo-1-methyl-1,2,3,4-tetrahydronaphtho[1,8-bc]azepine, $17,(1.92 \mathrm{~g}, 52 \%)$ as a light brown oil which was used without further purification. ${ }^{1} \mathrm{H}$ NMR $\left(400 \mathrm{MHz}, \mathrm{CDCl}_{3}\right): \delta 7.59$ (d, $J$ $=8.2 \mathrm{~Hz}, 1 \mathrm{H}), 7.47(\mathrm{~d}, J=7.5 \mathrm{~Hz}, 1 \mathrm{H}), 7.27(\mathrm{dd}, J=8.2,7.8$ $\mathrm{Hz}, 1 \mathrm{H}), 6.82(\mathrm{~d}, J=7.5 \mathrm{~Hz}, 1 \mathrm{H}), 6.67(\mathrm{~d}, J=7.8 \mathrm{~Hz}, 1 \mathrm{H})$, $3.12(\mathrm{t}, J=6.9 \mathrm{~Hz}, 2 \mathrm{H}), 3.07(\mathrm{t}, J=6.6 \mathrm{~Hz}, 2 \mathrm{H}), 2.91(\mathrm{~s}, 3 \mathrm{H})$, $2.02(\mathrm{tt}, J=6.9,6.6 \mathrm{~Hz}, 2 \mathrm{H}) ;{ }^{13} \mathrm{C}$ NMR $\left(100 \mathrm{MHz} \mathrm{CDCl}_{3}\right): \delta$ 29.41, 34.17, 41.35, 56.73, 76.92, 77.23, 77.55, 109.3, 118.53, 120.74, 125.19, 127.06, 129.09, 129.81, 134.25, 139.77, 153.13.

1-(1-Methyl-1,2,3,4-tetrahydronaphtho[1,8-bc]azepin-7yl)propan-1-one (9). 7-Bromo-1-methyl-1,2,3,4tetrahydronaphtho[1,8-bc]azepine, $17,(730 \mathrm{mg}, 2.64 \mathrm{mmol})$ was dissolved in dry THF $(15 \mathrm{~mL})$, and the mixture was cooled to $-78{ }^{\circ} \mathrm{C}$ under $\mathrm{N}_{2}$. A solution of $n$-BuLi in hexanes $(2.2 \mathrm{~mL}$, $1.6 \mathrm{M}, 3.5 \mathrm{mmol}$ ) was added dropwise with stirring. The mixture was allowed to stir for $20 \mathrm{~min}$ after the addition. Propionyl pyrrole $(350 \mathrm{mg}, 2.84 \mathrm{mmol}$ ) was added in one portion. The reaction was allowed to warm slowly to $-25{ }^{\circ} \mathrm{C}$, whereupon water was added $(3 \mathrm{~mL})$ with stirring. When the mixture reached $0{ }^{\circ} \mathrm{C}$, it was diluted with $\mathrm{Et}_{2} \mathrm{O}(200 \mathrm{~mL})$, and the organic phase was washed twice with $5 \%$ aq $\mathrm{NH}_{4} \mathrm{Cl}(100$ $\mathrm{mL}$ ea), dried over $\mathrm{Na}_{2} \mathrm{SO}_{4}$, and concentrated in vacuo. The residue was purified using column chromatography $\left(\mathrm{SiO}_{2}, 0-\right.$

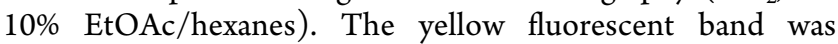


collected and concentrated. The residue was distilled bulb-tobulb under vacuum giving 1-(1-methyl-1,2,3,4tetrahydronaphtho[1,8-bc] azepin-7-yl)propan-1-one, 9, as a yellow oil $(240 \mathrm{mg}, 36 \%) .{ }^{1} \mathrm{H}$ NMR $\left(400 \mathrm{MHz} \mathrm{CDCl}_{3}\right): \delta$ $7.87(\mathrm{~d}, J=8.2 \mathrm{~Hz}, 1 \mathrm{H}), 7.57(\mathrm{~d}, J=7.2 \mathrm{~Hz}, 1 \mathrm{H}), 7.34(\mathrm{dd}, J=$ 8.2, $7.8 \mathrm{~Hz}, 1 \mathrm{H}), 7.08$ (d, $J=7.2 \mathrm{~Hz}, 1 \mathrm{H}), 6.75(\mathrm{~d}, J=7.8 \mathrm{~Hz}$, $1 \mathrm{H}), 3.22(\mathrm{~m}, 4 \mathrm{H}), 3.02(\mathrm{~s}, 3 \mathrm{H}), 3.01(\mathrm{q}, J=7.3 \mathrm{~Hz}, 2 \mathrm{H}), 2.14$ (quint, $J=6.7 \mathrm{~Hz}, 2 \mathrm{H}), 1.25(\mathrm{t}, J=7.3 \mathrm{~Hz}, 3 \mathrm{H}) ;{ }^{13} \mathrm{C} \mathrm{NMR}$ $\left(100 \mathrm{MHz}, \mathrm{CDCl}_{3}\right): \delta 205.89,152.86,144.10,134.90,132.63$, $128.19,127.14,126.66,123.40,116.53,108.67,56.43,41.02$, 35.55, 34.52, 29.50, 8.84.

HRMS (ESI): $[\mathrm{M}+\mathrm{Na}]^{+}$calcd for $\mathrm{C}_{17} \mathrm{H}_{19} \mathrm{NONa}^{+}$, 276.13588; found, 276.13584 .

6-Bromo-1H-benzo[g]indole (18). 5-Bromo-1-nitronaphthalene, $11,(4.00 \mathrm{~g}, 15.9 \mathrm{mmol})$ was added all at once with stirring to a solution of vinyl magnesium bromide in THF $(100 \mathrm{~mL}, 0.7$ $\mathrm{M}, 70 \mathrm{mmol}$ ) that had been cooled to $10{ }^{\circ} \mathrm{C}$ in an ice-water bath under $\mathrm{N}_{2}$. The reaction immediately warmed to $40{ }^{\circ} \mathrm{C}$. When the mixture cooled to $20{ }^{\circ} \mathrm{C}$, the ice bath was removed and stirring was continued for $1 \mathrm{~h}$. The reaction was cooled in an ice-water bath while a sat. aq solution of $\mathrm{NH}_{4} \mathrm{Cl}(5 \mathrm{~mL})$ was added with stirring. The mixture was dried with $\mathrm{CaCl}_{2}$, and the solids were removed by suction filtration and washed with a little ether. The organic solvents were removed in vacuo, and the residue was filtered with $250 \mathrm{~mL}$ of $25 \%$ ethyl acetate/ hexanes through a silica gel column $(\sim 10 \mathrm{~cm})$. The filtrate was concentrated in vacuo, giving crude 6-bromo- $1 H$-benzo $[g]$ indole, 18, $(8.17 \mathrm{mmol}, 51 \%)$ which was used without further purification. ${ }^{1} \mathrm{H}$ NMR (400 $\left.\mathrm{MHz}, \mathrm{CDCl}_{3}\right): \delta 8.91$ (br s, NH), $7.94(\mathrm{~d}, J=8.8 \mathrm{~Hz}, 1 \mathrm{H}), 7.93(\mathrm{~d}, J=8.0 \mathrm{~Hz}, 1 \mathrm{H}), 7.82(\mathrm{~d}, J=$ $8.8 \mathrm{~Hz}, 1 \mathrm{H}), 7.72(\mathrm{dd}, J=7.6,0.7 \mathrm{~Hz}, 1 \mathrm{H}), 7.33(\mathrm{dd}, J=8.0$, $7.6 \mathrm{~Hz}, 1 \mathrm{H}), 7.29$ (d, $J=2.9 \mathrm{~Hz}, 1 \mathrm{H}), 6.71(\mathrm{dd} J=2.9,0.7 \mathrm{~Hz}$, $1 \mathrm{H}) ;{ }^{13} \mathrm{C} \mathrm{NMR}\left(100 \mathrm{MHz}, \mathrm{CDCl}_{3}\right): \delta 130.50,128.95,128.24$, $125.89,124.66,124.31,123.43,123.09,122.45,119.85,119.29$, 104.60 .

6-Bromo-1-methyl-1H-benzo[g]indole (19). 6-Bromo-1Hbenzo $[g]$ indole, $18,(2.01 \mathrm{~g}, 8.17 \mathrm{mmol})$ was dissolved in dry DMF $(10 \mathrm{~mL})$. The solution was cooled in an ice-water bath, and $\mathrm{NaH}(0.90 \mathrm{~g}, 60 \%$ in oil, $22.5 \mathrm{mmol}$, washed with hexanes) was added in several portions. The reaction was stirred for 30 min before adding $\mathrm{CH}_{3} \mathrm{I}(2.26 \mathrm{~g}$, $9.55 \mathrm{mmol})$. Stirring was continued overnight. The reaction mixture was added dropwise to a rapidly stirred solution of $\mathrm{NaCl}(60 \mathrm{~g})$ and $\mathrm{NH}_{4} \mathrm{Cl}$ in water $(350 \mathrm{~mL})$. Stirring was continued for several hours until the solution cleared leaving an oily residue. The aqueous solution was decanted. The residue was taken up in $\mathrm{CH}_{2} \mathrm{Cl}_{2}(175 \mathrm{~mL})$. The decanted solution was extracted twice with $\mathrm{CH}_{2} \mathrm{Cl}_{2}$ (50 $\mathrm{mL}$ ea). The organic solutions were combined, washed twice with water $(150 \mathrm{~mL}$ ea $)$, dried over $\mathrm{CaCl}_{2}$, and concentrated in vacuo, leaving crude 6-bromo-1-methyl-1H-benzo[g]indole, 19, $(1.97 \mathrm{~g}, 93 \%)$ which was used without further purification. ${ }^{1} \mathrm{H}$ $\operatorname{NMR}\left(400 \mathrm{MHz}, \mathrm{CDCl}_{3}\right): \delta 8.36(\mathrm{~d}, J=8.2 \mathrm{~Hz}, 1 \mathrm{H}), 7.95(\mathrm{~d}, J$ $=8.8 \mathrm{~Hz}, 1 \mathrm{H}), 7.76(\mathrm{~d}, J=8.8 \mathrm{~Hz}, 1 \mathrm{H}), 7.69(\mathrm{~d}, J=7.5 \mathrm{~Hz}$, $1 \mathrm{H}), 7.27(\mathrm{dd}, J=8.2,7.6 \mathrm{~Hz}, 1 \mathrm{H}), 7.03(\mathrm{~d}, J=2.9 \mathrm{~Hz}, 1 \mathrm{H})$, 6.57 (d, $J=2.9 \mathrm{~Hz}, 1 \mathrm{H}), 4.16(\mathrm{~s}, 3 \mathrm{H}) .{ }^{13} \mathrm{C} \mathrm{NMR}(100 \mathrm{MHz}$, $\left.\mathrm{CDCl}_{3}\right): \delta 130.33,129.81,129.40,127.73,126.53,125.32$, 124.66, 124.20, 122.63, 120.43, 119.76, 102.18, 38.81.

6-Bromo-1-methyl-2,3-dihydro-1H-benzo[g]indole (20). 6Bromo-1-methyl-1H-benzo[g]indole, 19, (1.97 g, $7.57 \mathrm{mmol})$ was dissolved in glacial acetic acid $(50 \mathrm{~mL})$. Sodium cyanoborohydride $(5.0 \mathrm{~g}, 80 \mathrm{mmol})$ was added slowly in portions after which stirring was continued overnight. The reaction mixture was poured slowly into a solution of $\mathrm{Na}_{2} \mathrm{CO}_{3}$ in water $(800 \mathrm{~mL}) . \mathrm{Next}, \mathrm{NaCl}(130 \mathrm{~g})$ was added, and the aqueous mixture was extracted twice with $\mathrm{CH}_{2} \mathrm{Cl}_{2}$. The combined organic layers were dried over $\mathrm{CaCl}_{2}$ and concentrated in vacuo. The residue was filtered with $250 \mathrm{~mL}$ of $15 \%$ ethyl acetate/hexanes through a silica gel column $(\sim 10$ $\mathrm{cm})$. The filtrate was concentrated in vacuo, giving crude 6bromo-1-methyl-2,3-dihydro-1H-benzo $[g]$ indole, 20, (1.22 g, $61 \%)$. This material was dried on a vacuum pump before the next step. ${ }^{1} \mathrm{H}$ NMR $\left(400 \mathrm{MHz}, \mathrm{CDCl}_{3}\right): \delta 8.05(\mathrm{~d}, J=8.6 \mathrm{~Hz}$, $1 \mathrm{H}), 7.71(\mathrm{~d}, J=8.4 \mathrm{~Hz}, 1 \mathrm{H}), 7.64(\mathrm{~d}, J=7.3 \mathrm{~Hz}, 1 \mathrm{H}), 7.34(\mathrm{~d}$, $J=8.4 \mathrm{~Hz}, 1 \mathrm{H}), 7.14(\mathrm{dd}, J=8.0,7.9 \mathrm{~Hz}, 1 \mathrm{H}), 3.53(\mathrm{t}, J=8.7$ $\mathrm{Hz}, 2 \mathrm{H}), 3.12(\mathrm{~s}, 3 \mathrm{H}), 3.10(\mathrm{t}, J=8.7 \mathrm{~Hz}, 2 \mathrm{H}) .{ }^{13} \mathrm{C}$ NMR $(100$ $\left.\mathrm{MHz}, \mathrm{CDCl}_{3}\right): \delta 149.76,132.93,129.15,127.63,124.48$, 124.32, 123.89, 123.55, 122.76, 119.47, 58.34, 42.97, 29.33.

1-(1-Methyl-2,3-dihydro-1H-benzo[g]indol-6-yl)propan-1one (10). 6-Bromo-1-methyl-2,3-dihydro- $1 \mathrm{H}$-benzo $[\mathrm{g}]$ indole, 20, $(0.99 \mathrm{~g}, 3.78 \mathrm{mmol})$ was dissolved in dry THF $(15 \mathrm{~mL})$, and the solution was cooled to $-60{ }^{\circ} \mathrm{C}$ under $\mathrm{N}_{2}$. A solution of $n$-BuLi (2.6 mL, 1.6 M in hexanes) was added slowly dropwise. The reaction was allowed to stir for $10 \mathrm{~min}$ after the addition. Neat propionyl pyrrole $(0.47 \mathrm{~g}, 3.82 \mathrm{mmol})$ was added in one portion. Stirring at $-60{ }^{\circ} \mathrm{C}$ was continued for $10 \mathrm{~min}$. The cooling bath was removed. When the reaction warmed to -30 ${ }^{\circ} \mathrm{C}$, sat. aq $\mathrm{NH}_{4} \mathrm{Cl}(5 \mathrm{~mL})$ was added. The solvent was removed in vacuo. The residue was taken up in $15 \% \mathrm{CH}_{2} \mathrm{Cl}_{2} /$ hexanes $(200 \mathrm{~mL})$. The organic layer was washed twice with water $(200$ $\mathrm{mL}$ ea), dried over $\mathrm{CaCl}_{2}$, and concentrated in vacuo. The residue was purified using column chromatography $\left(\mathrm{SiO}_{2}, 0-\right.$ $30 \% \mathrm{EtOAc} /$ hexanes). Fractions containing the orange nonfluorescent band were collected, concentrated in vacuo, and dried under vacuum, giving 1-(1-methyl-2,3-dihydro- $1 \mathrm{H}$-benzo[g]indol-6-yl)propan-1-one, 10, (0.28 g, 31\%). ${ }^{1} \mathrm{H}$ NMR (400 $\left.\mathrm{MHz}, \mathrm{CDCl}_{3}\right): \delta 8.20(\mathrm{~d}, J=8.7 \mathrm{~Hz}, 1 \mathrm{H}), 7.84(\mathrm{~d}, J=8.4 \mathrm{~Hz}$, $1 \mathrm{H}), 7.59$ (d, $J=7.1 \mathrm{~Hz}, 1 \mathrm{H}), 7.34(\mathrm{~d}, J=8.7 \mathrm{~Hz}, 1 \mathrm{H}), 7.33$ (dd, $J=8.5,7.1 \mathrm{~Hz}, 1 \mathrm{H}), 3.52(\mathrm{t}, J=8.7 \mathrm{~Hz}, 2 \mathrm{H}), 3.12(\mathrm{~s}, 3 \mathrm{H})$, $3.10(\mathrm{t}, J=8.7 \mathrm{~Hz}, 2 \mathrm{H}), 3.00(\mathrm{q}, J=7.3 \mathrm{~Hz}, 2 \mathrm{H}), 1.25(\mathrm{t}, J=$ $7.3 \mathrm{~Hz}, 3 \mathrm{H}) ;{ }^{13} \mathrm{C}$ NMR (100 MHz, $\left.\mathrm{CDCl}_{3}\right): \delta 206.50,149.79$, $137.99,130.75,127.21,126.45,125.36,124.74,123.18,122.80$, 117.79, 58.07, 43.22, 35.95, 29.41, 8.80.

HRMS (ESI): $[\mathrm{M}+\mathrm{H}]^{+}$calcd for $\mathrm{C}_{16} \mathrm{H}_{17} \mathrm{NOH}^{+}, 240.13829$; found, 240.13833 .

\section{ASSOCIATED CONTENT}

\section{Supporting Information}

The Supporting Information is available free of charge on the ACS Publications website at DOI: 10.1021/acsomega.8b00423.

Emission spectra of 8-10 in various solvents; plots of computed emission maxima vs experimental values; and optimized structures for the ground and first excited states of $\mathbf{8 - 1 0}$ (PDF)

\section{AUTHOR INFORMATION}

\section{Corresponding Author}

*E-mail: cjabel@wm.edu (C.J.A.).

ORCID

Christopher J. Abelt: 0000-0002-0123-8390

\section{Author Contributions}

The manuscript was written through contributions of all authors.

\section{Notes}

The authors declare no competing financial interest. 


\section{ACKNOWLEDGMENTS}

We acknowledge the donors of the American Chemical Society Petroleum Research Fund.

\section{REFERENCES}

(1) Weber, G.; Farris, F. J. Synthesis and Spectral Properties of a Hydrophobic Fluorescent Probe: 6-Propionyl-2-(Dimethylamino) Naphthalene. Biochemistry 1979, 18, 3075-3078.

(2) Catalan, J.; Perez, P.; Laynez, J.; Blanco, F. G. Analysis of the Solvent Effect on the Photophysics Properties of 6-Propionyl-2(Dimethylamino) Naphthalene (PRODAN). J. Fluoresc. 1991, 1, 215223.

(3) Balter, A.; Nowak, W.; Pawełkiewicz, W.; Kowalczyk, A. Some Remarks on the Interpretation of the Spectral Properties of Prodan. Chem. Phys. Lett. 1988, 143, 565-570.

(4) Kawski, A. Ground-and Excited-State Dipole Moments of 6Propionyl-2-(Dimethylamino) Naphthalene Determined from Solvatochromic Shifts. Z. Naturforsch., A: Phys. Sci. 1999, 54, 379-381.

(5) Samanta, A.; Fessenden, R. W. Excited State Dipole Moment of PRODAN as Determined from Transient Dielectric Loss Measurements. J. Phys. Chem. A 2000, 104, 8972-8975.

(6) Vequi-Suplicy, C. C.; Coutinho, K.; Lamy, M. T. New Insights on the Fluorescent Emission Spectra of Prodan and Laurdan. J. Fluoresc. 2015, 25, 621-629.

(7) Karukstis, K. K.; Suljak, S. W.; Waller, P. J.; Whiles, J. A.; Thompson, E. H. Z. Fluorescence Analysis of Single and Mixed Micelle Systems of SDS and DTAB. J. Phys. Chem. 1996, 100, 1112511132.

(8) Karukstis, K. K.; Frazier, A. A.; Martula, D. S.; Whiles, J. A. Characterization of the Microenvironments in AOT Reverse Micelles using Multidimensional Spectral Analysis. J. Phys. Chem. 1996, 100, $11133-11138$

(9) Adhikary, R; Barnes, C. A.; Petrich, J. W. Solvation Dynamics of the Fluorescent Probe PRODAN in Heterogeneous Environments: Contributions from the Locally Excited and Charge-Transferred States. J. Phys. Chem. B 2009, 113, 11999-12004.

(10) Novaira, M.; Moyano, F.; Biasutti, M. A.; Silber, J. J.; Correa, N. M. An Example of how to use AOT Reverse Micelle Interfaces to Control a Photoinduced Intramolecular Charge-Transfer Process. Langmuir 2008, 24, 4637-4646.

(11) Agazzi, F. M.; Rodriguez, J.; Falcone, R. D.; Silber, J. J.; Correa, N. M. PRODAN Dual Emission Feature to Monitor BHDC Interfacial Properties Changes with the External Organic Solvent Composition. Langmuir 2013, 29, 3556-3566.

(12) Parusel, A. B. J.; Nowak, W.; Grimme, S.; Köhler, G. Comparative Theoretical Study on Charge-Transfer Fluorescence Probes: 6-Propanoyl-2-(N,N-Dimethylamino)Naphthalene and Derivatives. J. Phys. Chem. A 1998, 102, 7149-7156.

(13) Parusel, A. B. J.; Schneider, F. W.; Köhler, G. An Ab Initio Study on Excited and Ground State Properties of the Organic Fluorescence Probe PRODAN. J. Mol. Struct.: THEOCHEM 1997, 398, 341-346.

(14) Ilich, P.; Prendergast, F. G. Singlet Adiabatic States of Solvated PRODAN: A Semiempirical Molecular Orbital Study. J. Phys. Chem. 1989, 93, 4441-4447.

(15) Mennucci, B.; Caricato, M.; Ingrosso, F.; Cappelli, C.; Cammi, R.; Tomasi, J.; Scalmani, G.; Frisch, M. J. How the Environment Controls Absorption and Fluorescence Spectra of PRODAN: A Quantum-Mechanical Study in Homogeneous and Heterogeneous Media. J. Phys. Chem. B 2008, 112, 414-423.

(16) Zharkova, O. M.; Rakhimov, S. I.; Morozova, Y. P. QuantumChemical Investigation of the Spectral Properties of Fluorescent Probes Based on Naphthalene Derivatives (Prodan, Promen). Russ. Phys. J. 2013, 56, 411-419.

(17) Wermuth, G.; Rettig, W. The Interaction of Close-Lying Excited States: Solvent Influence on Fluorescence Rate and Polarization in Substituted Indolines. J. Phys. Chem. 1984, 88, 2729-2735.

(18) Grabowski, Z. R; Rotkiewicz, K.; Siemiarczuk, A. Dual Fluorescence of Donor-Acceptor Molecules and the Twisted Intra- molecular Charge Transfer (TICT) States. J. Lumin. 1979, 18, 420424.

(19) Köhler, G.; Rechthaler, K.; Grabner, G.; Luboradzki, R.; Suwińska, K.; Rotkiewicz, K. Structure of Cage Amines as Models for Twisted Intramolecular Charge-Transfer States. J. Phys. Chem. A 1997, $101,8518-8525$.

(20) Lobo, B. C.; Abelt, C. J. Does PRODAN Possess a Planar Or Twisted Charge-Transfer Excited State? Photophysical Properties of Two PRODAN Derivatives. J. Phys. Chem. A 2003, 107, 1093810943.

(21) Everett, R. K.; Nguyen, H. A. A.; Abelt, C. J. Does PRODAN Possess an O-TICT Excited State? Synthesis and Properties of Two Constrained Derivatives. J. Phys. Chem. A 2010, 114, 4946-4950.

(22) Davis, B. N.; Abelt, C. J. Synthesis and Photophysical Properties of Models for Twisted PRODAN and Dimethylaminonaphthonitrile. J. Phys. Chem. A 2005, 109, 1295-1298.

(23) Jockusch, S.; Zheng, Q.; He, G. S.; Pudavar, H. E.; Yee, D. J.; Balsanek, V.; Halim, M.; Sames, D.; Prasad, P. N.; Turro, N. J. TwoPhoton Excitation of Fluorogenic Probes for Redox Metabolism: Dramatic Enhancement of Optical Contrast Ratio by Two-Photon Excitation. J. Phys. Chem. C 2007, 111, 8872-8877.

(24) Benedetti, E.; Kocsis, L. S.; Brummond, K. M. Synthesis and Photophysical Properties of a Series of Cyclopenta [b] Naphthalene Solvatochromic Fluorophores. J. Am. Chem. Soc. 2012, 134, 1241812421.

(25) Brummond, K. M.; Kocsis, L. S. Intramolecular DidehydroDiels-Alder Reaction and its Impact on the Structure-Function Properties of Environmentally Sensitive Fluorophores. Acc. Chem. Res. 2015, 48, 2320-2329.

(26) Benedetti, E.; Veliz, A. B. E.; Charpenay, M.; Kocsis, L. S.; Brummond, K. M. Attachable Solvatochromic Fluorophores and Bioconjugation Studies. Org. Lett. 2013, 15, 2578-2581.

(27) Gros, C.; Labouesse, B. Study of the Dansylation Reaction of Amino Acids, Peptides and Proteins. Eur. J. Biochem. 1969, 7, 463470.

(28) Gray, W. R. [12] Dansyl Chloride Procedure. Methods Enzymol. 1967, 11, 139-151.

(29) Rettig, W.; Lapouyade, R. Fluorescence probes based on twisted intramolecular charge transfer (TICT) states and other adiabatic photoreactions. Topics in Fluorescence Spectroscopy; Springer, 2002; pp 109-149.

(30) Grabowski, Z. R.; Rotkiewicz, K.; Rettig, W. Structural Changes Accompanying Intramolecular Electron Transfer: Focus on Twisted Intramolecular Charge-Transfer States and Structures. Chem. Rev. 2003, 103, 3899-4031.

(31) Silvonek, S. S.; Giller, C. B.; Abelt, C. J. Alternate Syntheses of Prodan and Acrylodan. Org. Prep. Proced. Int. 2005, 37, 589-594.

(32) Dalpozzo, R.; Bartoli, G. Bartoli Indole Synthesis. Curr. Org. Chem. 2005, 9, 163-178.

(33) Bartoli, G.; Dalpozzo, R.; Nardi, M. Applications of Bartoli Indole Synthesis. Chem. Soc. Rev. 2014, 43, 4728-4750.

(34) Reichardt, C.; Welton, T. Solvents and Solvent Effects in Organic Chemistry; Wiley-VCH Verlag GmbH, 2011.

(35) Cerezo, F. M.; Rocafort, S. C.; Sierra, P. S.; García-Blanco, F.; Oliva, C. D.; Sierra, J. C. Photophysical Study of the Probes Acrylodan (1-[6-(Dimethylamino) Naphthalen-2-Y1]Prop-2-En-1-One), ANS (8Anilinonaphthalene-1-Sulfonate) and Prodan (1-[6-(Dimethylamino) Naphthalen-2-Y1]Propan-1-One) in Aqueous Mixtures of various Alcohols. Helv. Chim. Acta 2001, 84, 3306-3312.

(36) Marini, A.; Muñoz-Losa, A.; Biancardi, A.; Mennucci, B. What is Solvatochromism? J. Phys. Chem. B 2010, 114, 17128-17135.

(37) Green, A. M.; Naughton, H. R.; Nealy, Z. B.; Pike, R. D.; Abelt, C. J. Carbonyl-Twisted 6-Acyl-2-Dialkylaminonaphthalenes as Solvent Acidity Sensors. J. Org. Chem. 2013, 78, 1784-1789.

(38) Nikitina, Y. Y.; Iqbal, E. S.; Yoon, H. J.; Abelt, C. J. Preferential Solvation in Carbonyl-Twisted PRODAN Derivatives. J. Phys. Chem. A 2013, 117, 9189-9195. 
(39) Yoon, A. H.; Whitworth, L. C.; Wagner, J. D.; Abelt, C. J. 2,5PRODAN Derivatives as Highly Sensitive Sensors of Low Solvent Acidity. Molecules 2014, 19, 6415-6427.

(40) Bakalova, S. M.; Kaneti, J. Solvent induced shifts of electronic spectra IV. Computational Study on PRODAN Fluorescence and Implications to the Excited State Structure. Spectrochim. Acta, Part A 2009, 72, 36-40.

(41) Gao, X.; Zhang, Y.; Wang, B. Naphthalene-Based Water-Soluble Fluorescent Boronic Acid Isomers Suitable for Ratiometric and Off-on Sensing of Saccharides at Physiological pH. New J. Chem. 2005, 29, 579-586.

(42) Katritzky, A. R.; Yang, Z.; Lam, J. N. Substituted (Carbazol-9Yl)(Benzotriazol-1-Yl) Methanes: Novel Acyl Anion Equivalents. J. Org. Chem. 1991, 56, 6917-6923. 